\section{Gardenia jasminoides Height Control Using a Photoselective Polyethylene Film}

\author{
Christos Lykas ${ }^{1}$, Constantinos Kittas ${ }^{2,5}$, and Nikolaos Katsoulas ${ }^{3}$ \\ University of Thessaly, School of Agricultural Sciences, Department of \\ Agriculture, Crop Production and Rural Environment, Fytokou Street, \\ N. Ionia, 38446, Magnesia, Greece
}

\section{Maria Papafotiou ${ }^{4}$ Agricultural University of Athens, Department of Crop Science, Laboratory of Floriculture and Landscape Architecture, Iera Odos 75, 11855 Athens, Greece}

Additional index words. ornamentals, cuttings, growth regulation, light filtering, cover material, red to far red, height reduction

\begin{abstract}
The use of chemical growth retardants is a standard practice for compact gardenia plant production. The aim of this study was to investigate the possibility of using a photoselective polyethylene greenhouse covering film as an alternative to chemical treatment for production of compact potted gardenia (Gardenia jasminoides Ellis) plants. Two types of experiments were carried out: 1) on gardenia cuttings rooted in rooting benches; and 2) on young potted plants grown under low tunnels. In both experiments, two types of cover materials were used: 1) a photoselective polyethylene (P-PE), filtering light within the wavelength range 600 to $750 \mathrm{~nm}$; and 2) a common polyethylene film (C$\mathrm{PE}$ ) routinely used in greenhouse practice. Values of photosynthetically active radiation (in a wavelength of 400 to $700 \mathrm{~nm}$ ), cover materials' spectral properties (in a wavelength range of 400 to $1100 \mathrm{~nm}$ ), air temperature, and relative humidity were recorded inside the rooting benches and under the low tunnels. Plant growth parameters (main shoot length and leaf area and lateral shoot number, leaf area, and fresh and dry weight) were determined along the growth cycle. Cuttings rooted under the P-PE film received light with high $\zeta_{n}$ values (ratio of $R_{n}: 655$ to $665 \mathrm{~nm}$ to far red $F R_{n}: 725$ to $735 \mathrm{~nm}$ ) and high blue (B: 400 to $500 \mathrm{~nm})$ to red (R: 600 to $700 \mathrm{~nm})$ ratio $(B: R)$ and were $68.7 \%$ shorter and had $21 \%$ lower leaf area compared with cuttings rooted under the C-PE film. Similarly, plants that were rooted and then grown under the low tunnels covered with the P-PE film, compared with plants rooted and grown under C-PE film, were 59\% shorter, had $85 \%$ lower leaf area, $89 \%$ lower fresh weight, and $86 \%$ lower dry weight, whereas they did not produce lateral shoots. However, plants rooted under the C-PE film and then grown under the P-PE-covered low tunnels were $26 \%$ shorter and developed fewer laterals than plants rooted and grown under tunnels covered with C-PE film. Finally, plants rooted under the P-PE film and then grown under tunnels covered with C-PE film developed into compact, well-shaped plants, because they had a drastic reduction of height $(56 \%)$ without an effect on leaf area, shoot and leaf fresh and dry weight, and the number of lateral shoots.
\end{abstract}

A wide range of potted plants is treated with chemical regulators to obtain compact highquality plants (Larson, 1992; Pobudkiewicz and Treder, 2006). In gardenia potted plant cultivation, the use of chemical growth retardants is a standard practice to control stem elongation needed for compact plant production. Daminozide, chlormequat chloride, or

Received for publication 14 Apr. 2008. Accepted for publication 28 July 2008.

We acknowledge the Plastika Kritis S.A. for offering the cover materials for the experimental purposes of this research paper.

${ }^{1}$ Dr. Agronomist.

${ }^{2}$ Professor.

${ }^{3}$ Lecturer.

${ }^{4}$ Assistant Professor.

${ }^{5}$ To whom reprint requests should be addressed; e-mail ckittas@uth.gr the Pr state, whereas red light leads to a high proportion of Pfr (Khattak et al., 2004).

Light quality is often characterized by the $\zeta_{n}$ value that is the ratio of photons in the red $\left(\mathrm{R}_{\mathrm{n}}: 655\right.$ to $\left.665 \mathrm{~nm}\right)$ to the far-red $\left(\mathrm{FR}_{\mathrm{n}}: 725\right.$ to $735 \mathrm{~nm}$ ) wavelength ranges and/or by the ratio of blue (B: 400 to $500 \mathrm{~nm}$ ) to red (R: 600 to $700 \mathrm{~nm}$ ) wavelength ranges. Photoselective plastic films, with red- or far-red-absorbing (or reflecting) dyes, could give a relatively inexpensive nonchemical alternative for growth control of horticultural crops (Rajapakse et al., 1999). For this reason, several plastic and pigment manufacturers are working to develop such photoselective materials (Murakami et al., 1997; Van Haeringen et al., 1998). Indeed, such films, inducing a low $\mathrm{R}_{\mathrm{n}}: \mathrm{FR}_{\mathrm{n}}$ ratio, were found to reduce shoot elongation in a number of species (Oyaert et al., 1999; Runkle and Heins, 2002). Other authors refer that far-red (FR: 700 to $800 \mathrm{~nm}$ ) light-filtering films also resulted in reduced shoot elongation in some species, whereas in other cases, a high R:FR (600 to 700/700 to $800 \mathrm{~nm})$ did not affect shoot elongation (Cerny et al., 2003). Although most of the work on light quality and stem elongation has focused mainly on R:FR ratio, it has been shown that phytochrome does undergo lightinduced changes in the blue region of the spectrum and phytochrome phototransformation is sensitive to B light (Everett and Briggs, 1970; Pratt and Briggs, 1966). Warpeha and Kaufman (1989) and Britz and Sager (1990) have suggested that B light may be involved in the control of stem elongation in response to light quality independent of phytochrome involvement. As is also stressed by Casal and Smith (1989), it seems that blue light inhibits internode's extension only if it is combined with low $\zeta_{\mathrm{b}}$ [ratio of R (600 to $700 \mathrm{~nm}$ ) to FR ( 700 to 800 $\mathrm{nm})]$ values. Blue light and the R:FR ratio independently regulate growth by varying magnitudes in long-day plants. In other species, an FR environment can suppress flower initiation or development (Runkle and Heins, 2002).

One of the limitations of photoselective (P) polyethylene (PE) films is that they reduce photosynthetic photon flux density $(P P F D)$ affecting the photosynthetic rate of the plants (Wilson and Rajapakse, 2001). Furthermore, light intensity and light quality were related to lateral branching (Holmes and Smith, 1977; Muir and Zhu, 1983) and other morphological adaptations (Mortensen and Strømme, 1987), which are very important for well-shaped compact plant production.

To use this technology in commercial greenhouses for compact potted gardenia plant production, more information about the effect of light quality and quantity as well as the necessary period of treatment on gardenia cuttings and transplanted plants is needed. This work aims at investigating the possibility of using photoselective polyethylene films that modify R:FR and $\mathrm{B}: \mathrm{R}$ ratios as an alternative to chemicals use for greenhouse production of potted compact gardenia plants. 


\section{Materials and Methods}

Greenhouse facilities and plant material. The experiments were carried out in a commercial plastic covered greenhouse, eastwest oriented, located near Volos (lat. $39^{\circ} 20^{\prime}$, long. $23^{\circ} 00^{\prime}$, alt. $10 \mathrm{~m}$ ) on the coastal area of eastern Greece. The greenhouse was cultivated with gardenia potted plants (Gardenia jasminoides Ellis) and was equipped with rooting benches used for the propagation of the plants. Each rooting bench was built $\approx 50 \mathrm{~cm}$ from the greenhouse floor, had a total covered area of $4 \mathrm{~m}^{2}$, a volume of $3.2 \mathrm{~m}^{3}$, and was equipped with a highpressure water fogging system. Furthermore, a substrate heating system of plastic pipes was used to obtain a substrate temperature of $22{ }^{\circ} \mathrm{C}$. One of the two rooting benches used for the purposes of this study was covered with a common polyethylene film (C-PE), whereas the second rooting bench was covered with photoselective polyethylene (P-PE) film, which, in comparison with the C-PE film, modified the light transmission in the wavelengths between $500 \mathrm{~nm}$ and $800 \mathrm{~nm}$. The PE films totally covered the rooting benches, whereas a gap of $5 \mathrm{~cm}$ was left near the lower level of the bench for ventilation purposes. Accordingly, almost all light reaching the cuttings passed through the PE film. The two PE films had a thickness of $180 \mu \mathrm{m}$ and were supplied by Plastika Kritis S.A. (Heraclion, Crete, Greece). After rooting, cuttings were transferred under two low tunnels (length $1.5 \mathrm{~m}$, width $1 \mathrm{~m}$, and height $1.1 \mathrm{~m}$ ) covered by a P-PE or a C-PE film, and placed inside a greenhouse covered by a C-PE film.

Axillary shoot cuttings of gardenia plants of similar height with three nodes and two pairs of leaves were rooted in the two rooting benches described previously during fall of 2002 and 2004 in trays $(50 \mathrm{~cm} \times 28 \mathrm{~cm})$ of 28 site-holes each. Each hole had a diameter of $7 \mathrm{~cm}$ and was filled with a peat:coco:perlite substrate mixture (3:3:1 by volume). The cuttings' density in the rooting benches was 46 cuttings $/ \mathrm{m}^{2}$. Cuttings were inserted in the substrate up to the first defoliated node. During 2002, cuttings were rooted and remained in the rooting trays in the rooting benches for $60 \mathrm{~d}$ after planting. In 2004, $15 \mathrm{~d}$ after planting, the rooted cuttings were transplanted in plastic pots $20 \mathrm{~cm}$ in diameter filled with the same substrate mixture described previously and placed under the low tunnels with a pot density of 4.6 pots $/ \mathrm{m}^{2}$. Care was taken during transplanting the lower node of the rooted cuttings to reach the level of the pot rim. The cuttings rooted under the C-PE or the P-PE rooting bench were transplanted under either the C-PE or PPE tunnel. Fertigation of potted plants was performed every $2 \mathrm{~d}$ by a drip fertigation system. A nutrient solution with $\mathrm{pH}$ of 6.2 and an electrical conductivity of $1.5 \mathrm{dS} \cdot \mathrm{m}^{-1}$, having the following composition in $\mathrm{ppm}$ $\mathrm{NO}_{3}{ }^{-}$90.2, $\mathrm{NH}_{4}{ }^{+}$63.5, $\mathrm{K}^{+} 220, \mathrm{PO}_{4}{ }^{3-}$ 69.5, $\mathrm{Ca}^{2+} 220, \mathrm{Mg}^{2+} 60, \mathrm{SO}_{4}{ }^{2-} 320, \mathrm{Fe}^{2+, 3+} 3, \mathrm{Cu}^{2+}$ $0.3, \mathrm{Zn}^{2+} 0.23$, was provided to the plants.
Climate measurements. The following climatic data were measured outside and inside each rooting bench and each low tunnel: air temperature $\left(\mathrm{T},{ }^{\circ} \mathrm{C}\right)$ and water vapor pressure $(\mathrm{e}, \mathrm{kPa})$ by ventilated psychrometers (wet and dry bulb) (Model VP1; Delta-T Devices, Cambridge, UK), global radiation $\left(\mathrm{R}_{\mathrm{s}}\right.$, in $\left.\mathrm{W} \cdot \mathrm{m}^{-2}\right)$ by pyranometers (Model CM-6; Kipp and Zonen, Delft, The Netherlands), placed $2 \mathrm{~m}$ aboveground and at the center of each greenhouse; and photosynthetically active radiation $(P A R)(P P F D$, in $\mu \mathrm{mol} \cdot \mathrm{m}^{-2} \cdot \mathrm{s}^{-1}$ ) by quantum sensors (Model LI-190SA; LI-COR, Lincoln, NE).

All the previously mentioned measurements were collected by data logger system (Model DL3000; Delta-T Devices). Measurements took place every $30 \mathrm{~s}$ and $10-\mathrm{min}$ average values were recorded.

Film spectral properties. Measurements of the spectral transmittance of the two cover materials were made in the laboratory using a LI-COR portable spectroradiometer (LI-1800) equipped with a 10-W glass halogen lamp and an external integrating sphere (LI-1800-12S) internally coated with barium sulphate. More details concerning the instrument and the measuring technique are given by Kittas and Baille (1998). Measurements in the laboratory using the integrated sphere were carried out on samples taken before the installation of the films in the field, whereas measurements in the field using the LI-COR portable spectroradiometer were made under clear sky conditions between 1100 and $1300 \mathrm{HR}$ (local time) at an interval of $3 \mathrm{~min}$ alternatively in the open air and in the middle of the low tunnels. All spectral data were expressed as radiation intensity flux distribution in $\mathrm{W} \cdot \mathrm{m}^{-2} \cdot \mathrm{nm}^{-1}$

The greenhouse transmission $(\tau)$ in the PAR (400 to $700 \mathrm{~nm}$ ), the near-infrared radiation (NIR) (700 to $1100 \mathrm{~nm})$, and in the total band ( 400 to $1100 \mathrm{~nm}$ ) were then obtained by calculating the ratios of radiation fluxes measured below the material and outside.

The knowledge of the previous transmission coefficients allows estimating the amount of radiation entering the greenhouse in the previously mentioned broad wavelength ranges $P A R, \mathrm{NIR}$, and total. However, this information is not sufficient for assessing the photomorphogenetic effects of light. The literature on plant photomorphogenesis indicates that two main photoreceptors are involved in the perception of light quality, the phytochrome, and the cryptochrome (Chen et al., 2004; Spalding and Folta, 2005).

The easiest and most frequent way for characterizing the phytochrome response is to calculate the ratio of red to far-red light, which is generally quoted as $\zeta$. A wide range of wavelengths has been used for $\zeta$ determination in the literature. According to Kittas et al. (1999), two range bands are used: a narrow band ratio $\zeta_{n}[R(655$ to $665 \mathrm{~nm})$ to FR (725 to $735 \mathrm{~nm})]$ and a broader wavelength rage ratio $\zeta_{\mathrm{b}}[\mathrm{R}(600$ to $700 \mathrm{~nm})$ to $\mathrm{FR}$ (700 to $800 \mathrm{~nm})$ ].
Because the photochemical properties of the cryptochrome are not yet known, the simplest way to characterize the morphogenetically active radiation for this photoreceptor is to consider the photon flux in the broadband from 400 to $500 \mathrm{~nm}$ (Maas and Bakx, 1995; Rajapakse and Kelly, 1995). In this study, the values of $\zeta_{b}$ and $\zeta_{n}$ and the following ratios of radiation fluxes were determined: $\mathrm{B}$ (400 to $500 \mathrm{~nm})$ to $\mathrm{R}(600$ to $700 \mathrm{~nm}$ ), and B (400 to $500 \mathrm{~nm}$ ) to FR (700 to $800 \mathrm{~nm}$ ) to characterize radiation effects on cryptochrome. In addition, following Sager et al. (1988), the phytochrome photoequilibrium $\varphi$ was also calculated.

Finally, calculations of the following ratios relative to $P P F D$ were also performed: the relative amount of $P A R$ radiation with respect to the total radiation and the $P A R$ to NIR radiation ratio.

Crop measurements. During Oct. and Nov. 2002, detailed measurements on cutting growth were carried out. Thus, seven cuttings were randomly selected from each rooting bench and their height (from pot rim), leaf area, and dry weight (dried $24 \mathrm{~h}$ at $105{ }^{\circ} \mathrm{C}$ ) were measured by plant destructive measurements carried out every $10 \mathrm{~d}$ during the rooting period. The cuttings removed were replaced in the rooting benches. During Sept. of 2004 to Apr. of 2005, detailed measurements on transplanted plants were carried out. Thus, during the period after transplanting, the plant height and the number of lateral shoots of seven randomly selected plants were measured every $15 \mathrm{~d}$ for a period of $225 \mathrm{~d}$ after transplanting, whereas the leaf area and leaf and shoot fresh and dry weights of the seven plants were destructively measured only at the end of the experimental period.

Statistical analysis. The program SPSS (14.0 for Windows standard version; SPSS Inc., Chicago, IL) was used for the statistical analysis. The significance of the results was tested by one-way analysis of variance at $P=0.05$.

\section{Results}

Microclimate under the rooting benches and low tunnels. The mean values of air temperature, vapor pressure deficit, and relative humidity measured under the two rooting benches and the low tunnels during the experiment period are presented in Table 1. It can be seen that the values observed were similar for the C-PE- and P-PE-covered structures, because the heating system used was adjusted so that it could keep similar values of air temperature for both cases, whereas the fogging system maintained similar values of vapor pressure deficit.

The transmission, reflection, and absorption of the two cover materials in several wavelength ranges as measured in the laboratory using a LI-COR portable spectroradiometer and an external integrating sphere, before their installation in the rooting benches and the low tunnels, are presented in Table 2. As shown in Table 2, the PAR 
Table 1. Average values $( \pm \mathrm{SD})$ of air temperature, VPD, and relative humidity in rooting benches and low tunnels covered by the photoselective polyethylene film (P-PE) and the common polyethylene (C-PE) film.

\begin{tabular}{|c|c|c|c|c|}
\hline & \multicolumn{2}{|c|}{ Rooting benches } & \multicolumn{2}{|c|}{ Low tunnels } \\
\hline & C-PE & P-PE & C-PE & P-PE \\
\hline Temperature $\left({ }^{\circ} \mathrm{C}\right)$ & $23.4 \pm 1.7$ & $23.4 \pm 1.5$ & $22.2 \pm 1.6$ & $23.1 \pm 1.7$ \\
\hline $\operatorname{VPD}(\mathrm{kPa})$ & $0.09 \pm 0.02$ & $0.15 \pm 0.06$ & $0.70 \pm 0.1$ & $0.70 \pm 0.1$ \\
\hline Relative humidity (\%) & $96.9 \pm 1.5$ & $94.8 \pm 4.5$ & $73.6 \pm 1.6$ & $74.6 \pm 1.7$ \\
\hline
\end{tabular}

$\mathrm{VPD}=$ vapor pressure deficit.

Table 2. Spectral properties of the photoselective polyethylene film (P-PE) and of the common polyethylene film (C-PE) in several wavelength ranges.

\begin{tabular}{lccccccc}
\hline & \multicolumn{3}{c}{ C-PE } & & \multicolumn{3}{c}{ P-PE } \\
\cline { 2 - 4 } \cline { 5 - 7 } Light Band & TR & REF & ABS & & TR & REF & ABS \\
\hline B (400-500) & 0.79 & 0.15 & 0.05 & 0.61 & 0.11 & 0.28 \\
R (600-700) & 0.85 & 0.13 & 0.02 & 0.02 & 0.05 & 0.93 \\
FR (700-800) & 0.86 & 0.11 & 0.02 & 0.19 & 0.14 & 0.67 \\
PAR (400-700) & 0.83 & 0.14 & 0.03 & 0.33 & 0.07 & 0.60 \\
T (400-1,100) & 0.85 & 0.12 & 0.03 & 0.48 & 0.13 & 0.39 \\
NIR (700-1,100) & 0.87 & 0.10 & 0.03 & 0.60 & 0.17 & 0.23 \\
\hline
\end{tabular}

$\mathrm{TR}=$ transmission $; \mathrm{REF}=$ reflection; $\mathrm{ABS}=$ absorption; $\mathrm{B}=$ radiation for blue spectrum $400 \mathrm{~nm}$ to $500 \mathrm{~nm} ;$ $\mathrm{R}=$ radiation for red spectrum $600 \mathrm{~nm}$ to $700 \mathrm{~nm} ; \mathrm{FR}=$ radiation for far-red spectrum $700 \mathrm{~nm}$ to $800 \mathrm{~nm}$; $P A R=$ radiation for photosynthetically active radiation spectrum $400 \mathrm{~nm}$ to $700 \mathrm{~nm} ; \mathrm{T}=$ total radiation for spectrum $400 \mathrm{~nm}$ to $1100 \mathrm{~nm}$; NIR = radiation for near infrared spectrum $700 \mathrm{~nm}$ to $1100 \mathrm{~nm}$.

radiation transmission of the P-PE film was $\approx 60 \%$ less than the C-PE film, whereas the total light transmission of the P-PE film was $\approx 44 \%$ lower than the C-PE film. The P-PE film absorbed $\approx 98 \%$ more radiation in the $\mathrm{R}$ (600 to $700 \mathrm{~nm})$ and the FR ( 700 to $800 \mathrm{~nm}$ ) wavelength range regions than the C-PE film. As a result, the $\mathrm{R}$ and FR radiation transmission coefficients of the P-PE film were 0.02 and 0.19 , values that were $98 \%$ and $78 \%$ lower that the respective values found for the C-PE film.

Calculated values of several parameters obtained using the LI-COR portable spectroradiometer in situ are presented in Table 3. It can be seen that the values of the parameters calculated using in situ measurements are similar to those calculated using labora- tory measurements. The lower values observed for the parameters measured in situ can be attributed to the fact that: 1) measurements in the laboratory refer to radiation with vertical incidence over the cover material; and 2) the low tunnel frame reduces radiation transmission. The radiation transmission of the two low tunnels from $400 \mathrm{~nm}$ to $1100 \mathrm{~nm}$ is presented in Figure 1. It can be seen that the two cover materials have similar values (differences are $\approx 10 \%$ ) for wavelengths up to $500 \mathrm{~nm}$ and for wavelengths higher than $850 \mathrm{~nm}$, the P-PE film always have a lower transmission values. However, great differences in the transmission coefficient values of the two cover materials are observed between $550 \mathrm{~nm}$ and $800 \mathrm{~nm}$. The mean values of the transmission coefficient of the
C-PE and P-PE films in the range of $550 \mathrm{~nm}$ to $800 \mathrm{~nm}$ were 0.85 and 0.13 , respectively.

Under the C-PE film, the $\zeta_{\mathrm{n}}$ and $\zeta_{\mathrm{b}}$ values observed were 1.21 and 1.23 , respectively, whereas under the P-PE film, the respective values were 2.70 and 0.15 . Accordingly, it can be observed that as far as the narrow band is concerned, the P-PE film increases the ratio of red to far-red radiation entering the low tunnel compared with the C-PE, whereas in the broad band, the effect is the opposite. The values of $\varphi$ calculated were 0.72 and 0.59 for the C-PE and P-PE, respectively (Table 3 ). The $\mathrm{B}: \mathrm{R}$ and $\mathrm{B}: \mathrm{FR}$ ratios were also different between the two films with higher values being observed for the P-PE film, values that are in agreement with those observed by Oyaert et al. (1999). Concerning the parameters related to the PAR, PAR:total and $P A R:$ NIR ratios, they were $\approx 30 \%$ lower under the P-PE film than under the C-PE film.

Effects on cuttings stage. Figure 2 shows the evolution of cuttings height under the two $\mathrm{PE}$ films during the period of measurements. Statistical analysis revealed that cuttings grown under the C-PE film were significantly higher than those grown under the P-PE film. Statistically significant differences on their height observed $10 \mathrm{~d}$ after placing the cuttings under the rooting benches. Sixty $d$ after planting, cuttings rooted under the P-PEcovered bench were $\approx 69 \%$ shorter than cuttings rooted under the C-PE-covered bench.

In Figure 3 can be seen that for both treatments, the initial leaf area (LA) per cutting was similar. Measurements of cuttings' LA during the culture period showed a higher rate of LA increase for cuttings rooted under the C-PE film than under the P-PE film. Statistically significant differences of LA were observed $40 \mathrm{~d}$ after the beginning of measurements. Finally (60 d after planting), cuttings rooted under the P-PE film had $\approx 81 \%$ less LA than cuttings rooted under the C-PE-covered bench. Cuttings' leaves
Table 3. In situ calculated coefficients for the two low tunnels.

\begin{tabular}{lcr}
\hline Coefficient & C-PE & P-PE \\
\hline$\tau$ PAR & 0.78 & 0.29 \\
$\tau$ B & 0.76 & 0.54 \\
$\tau$ NIR & 0.84 & 0.61 \\
$\tau \mathrm{T}$ & 0.82 & 0.47 \\
$\zeta_{\mathrm{b}}$ & 1.23 & 0.15 \\
$\zeta_{\mathrm{n}}$ & 1.21 & 2.70 \\
$\varphi$ & 0.72 & 0.59 \\
$\mathrm{~B}: \mathrm{R}$ & 0.96 & 25.06 \\
$\mathrm{~B}: \mathrm{FR}$ & 0.94 & 2.88 \\
PAR:T & 0.96 & 0.61 \\
PAR:NIR & 0.93 & 0.47 \\
\hline
\end{tabular}

$\tau=$ radiation transmission to several wavelength ranges; $\mathrm{B}=$ radiation for blue spectrum $400 \mathrm{~nm}$ to $500 \mathrm{~nm} ; \mathrm{R}=$ radiation for red spectrum $600 \mathrm{~nm}$ to $700 \mathrm{~nm} ; \mathrm{FR}=$ radiation for far-red spectrum $700 \mathrm{~nm}$ to $800 \mathrm{~nm} ; P A R=$ radiation for photosynthetically active radiation spectrum 400 $\mathrm{nm}$ to $700 \mathrm{~nm}$; $\mathrm{T}=$ radiation for spectrum $400 \mathrm{~nm}$ to $1100 \mathrm{~nm} ;$ NIR = radiation for near infrared spectrum $700 \mathrm{~nm}$ to $1100 \mathrm{~nm} ; \zeta_{\mathrm{n}}=(655$ to $665 \mathrm{~nm})$ to $(725$ to $735 \mathrm{~nm})$ ratio; $\zeta_{\mathrm{b}}=\mathrm{R}$ to $\mathrm{FR}$ ratio; $\varphi=$ phytochrome photoequilibrium.

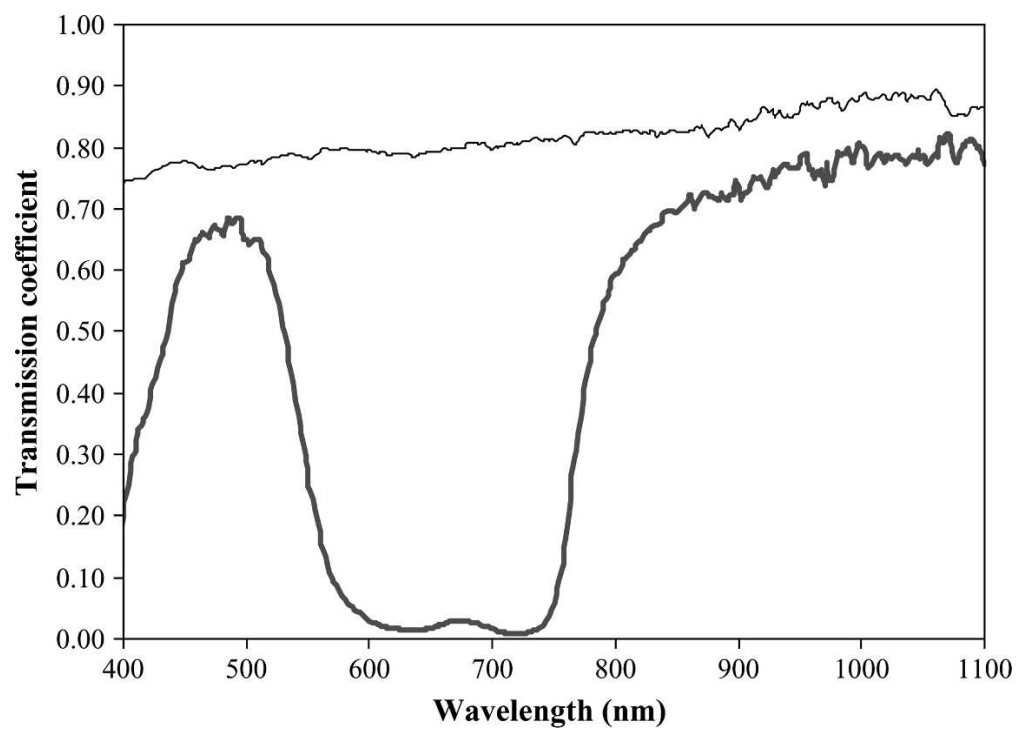

Fig. 1. Spectral transmission of the two tested cover materials measured in the field under the low tunnels. P-PE (-) and C-PE (-). 


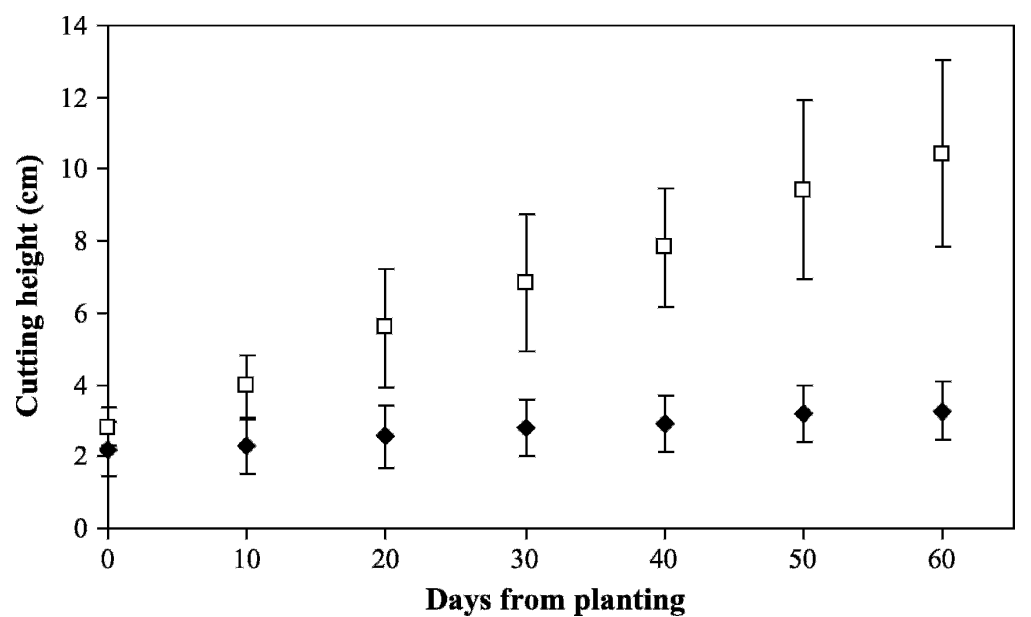

Fig. 2. Mean height of cuttings rooted under the P-PE $(\diamond)$ and C-PE $(\square)$ films. Vertical bars indicate \pm SD $(\mathrm{n}=24)$

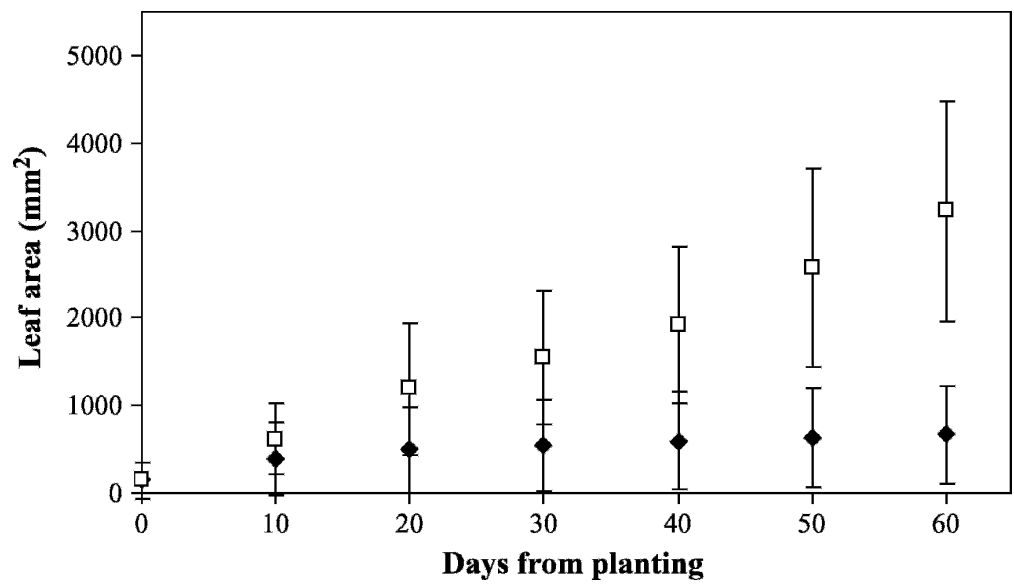

Fig. 3. Mean values of leaf area of cuttings rooted under P-PE ( $\bullet$ ) and C-PE ( $\square)$ films. Vertical bars indicate \pm SD $(n=7)$.

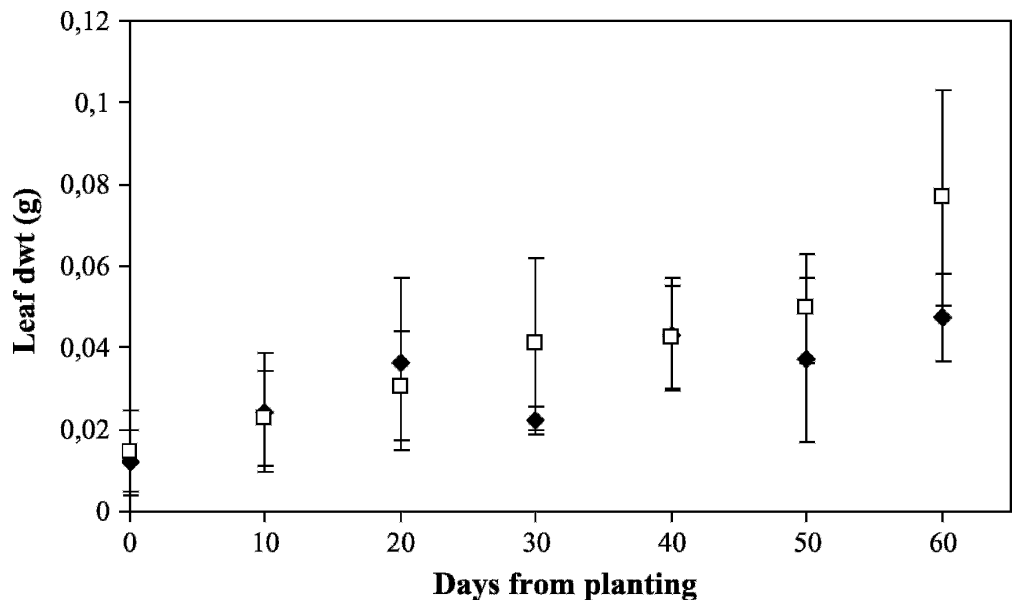

Fig. 4. Evolution of leaf dry weight (dwt) of cuttings rooted under the P-PE ( $\downarrow$ ) and C-PE ( $\square$ ) films. Vertical bars indicate $\pm \mathrm{SD}(\mathrm{n}=7)$

existing during planting or leaves developed immediately after placing the cuttings under the P-PE film (first $30 \mathrm{~d}$ after planting) were unaffected by light modification, whereas leaves developed $30 \mathrm{~d}$ after planting under the modified light regime were smaller (data not shown).

Leaf dry weight was slightly higher for cuttings rooted under the C-PE- than under the P-PE-covered rooting bench (Fig. 4).
However, no significant differences were observed between the two treatments showing that there were no effects of the modified light regime created under the two rooting benches on the dry mater of leaves. The same trend was observed for roots dry weight, but no significant differences were observed between the two treatments (data not shown).

Effects on potted plant stage. The evolution of potted plant shoot length during the period of measurements is presented in Figure 5. During this experimental period (Winter 2004 to Spring 2005), cuttings remained under the rooting benches for a period of $15 \mathrm{~d}$ and then transplanted in pots and placed under the low tunnels. The initial height of potted plants was $\approx 4.5 \mathrm{~cm}$ (with a SD of $\pm 1.7 \mathrm{~cm}$ ) for those rooted under the P-PE film and $\approx 10.4 \mathrm{~cm}( \pm 1.1 \mathrm{~cm})$ for those rooted under the C-PE film. Cuttings rooted under the C$\mathrm{PE}$-covered rooting bench and transplanted to the C-PE-covered low tunnel $\left(\mathrm{C}_{\mathrm{RB}} \mathrm{C}_{\mathrm{T}}\right)$ reached a final height $(180 \mathrm{~d}$ after transplanting) of $25.8 \mathrm{~cm}( \pm 3.5 \mathrm{~cm})$, whereas cuttings rooted under the C-PE-covered rooting bench and transplanted to the P-PEcovered low tunnel $\left(\mathrm{C}_{\mathrm{RB}} \mathrm{P}_{\mathrm{T}}\right)$ reached a final height of $19.2 \mathrm{~cm}( \pm 2.6 \mathrm{~cm})$, being $26 \%$ shorter than the $\mathrm{C}_{\mathrm{RB}} \mathrm{C}_{\mathrm{T}}$ plants. Concerning the cuttings rooted under the P-PE-covered rooting bench and transplanted to the C-PE$\left(\mathrm{P}_{\mathrm{RB}} \mathrm{C}_{\mathrm{T}}\right)$ or to the P-PE- $\left(\mathrm{P}_{\mathrm{RB}} \mathrm{P}_{\mathrm{T}}\right)$ covered low tunnel, their final height was $12.1 \mathrm{~cm}( \pm 3.2 \mathrm{~cm})$ and $9.7 \mathrm{~cm}( \pm 2.2 \mathrm{~cm})$, respectively, meaning that the P-PE film reduced the plant height by $20 \%$ during plant development under the low tunnel.

Statistically significant differences on $\mathrm{C}_{\mathrm{RB}} \mathrm{P}_{\mathrm{T}}$ and $\mathrm{C}_{\mathrm{RB}} \mathrm{C}_{\mathrm{T}}$ plant height were observed $120 \mathrm{~d}$ after planting, whereas statistically significant differences on $\mathrm{P}_{\mathrm{RB}} \mathrm{C}_{\mathrm{T}}$ and $\mathrm{C}_{\mathrm{RB}} \mathrm{P}_{\mathrm{T}}$ plant height were observed just $30 \mathrm{~d}$ after planting (Fig. 5), indicating that early-stage treatment of plants with light with high $\zeta_{n}$ values can be more effective for plant height reduction. Additionally, significant differences between the height of $\mathrm{C}_{\mathrm{RB}} \mathrm{C}_{\mathrm{T}}$ and $\mathrm{P}_{\mathrm{RB}} \mathrm{C}_{\mathrm{T}}$ plants and between $\mathrm{C}_{\mathrm{RB}} \mathrm{P}_{\mathrm{T}}$ and $\mathrm{P}_{\mathrm{RB}} \mathrm{P}_{\mathrm{T}}$ plant were observed. In contrast, no significant differences were observed between the height of $\mathrm{P}_{\mathrm{RB}} \mathrm{C}_{\mathrm{T}}$ and $\mathrm{P}_{\mathrm{RB}} \mathrm{P}_{\mathrm{T}}$ plants.

As far as lateral shoots are concerned (Fig. 6 ), the final number of lateral shoots developed was similar for $\mathrm{C}_{\mathrm{RB}} \mathrm{C}_{\mathrm{T}}$ and $\mathrm{P}_{\mathrm{RB}} \mathrm{C}_{\mathrm{T}}$ plants. $\mathrm{C}_{\mathrm{RB}} \mathrm{P}_{\mathrm{T}}$ plants developed very few laterals and $\mathrm{P}_{\mathrm{RB}} \mathrm{P}_{\mathrm{T}}$ plants did not develop any laterals.

At the end of the experimental period $(240 \mathrm{~d}$ after planting), only $\mathrm{P}_{\mathrm{RB}} \mathrm{P}_{\mathrm{T}}$ plants had lower leaf area and leaf and shoot fresh and dry weight compared with $\mathrm{C}_{\mathrm{RB}} \mathrm{C}_{\mathrm{T}}, \mathrm{C}_{\mathrm{RB}} \mathrm{P}_{\mathrm{T}}$, and $\mathrm{P}_{\mathrm{RB}} \mathrm{C}_{\mathrm{T}}$ plants (Table 4).

\section{Discussion}

Light quality modifications. As shown in Tables 1 and 2, the P-PE film induced a low $P A R$ transmission compared with C-PE film and subsequently reduced $P A R$ radiation by $\approx 60 \%$. A lower reduction $(\approx 30 \%)$ was 


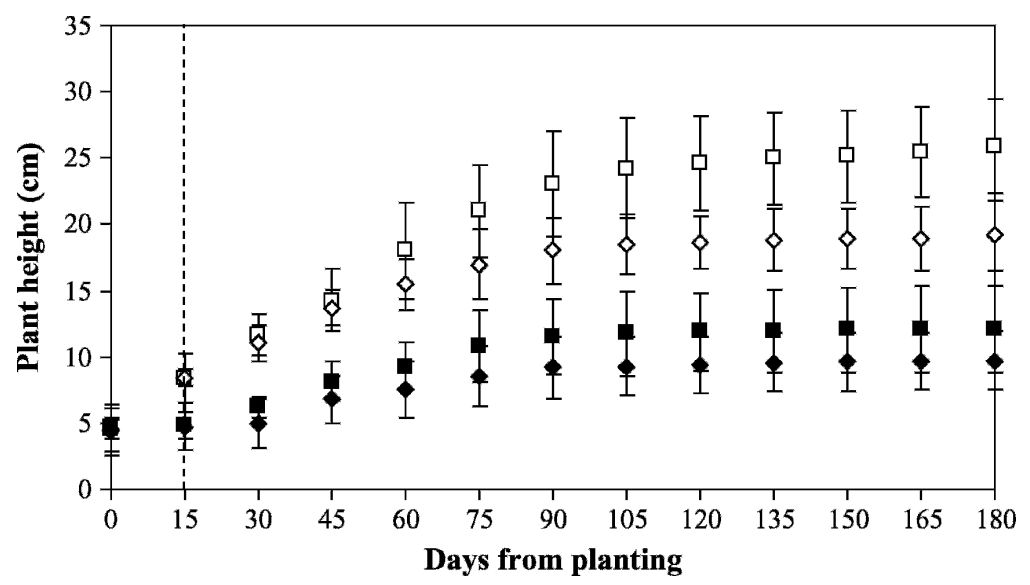

Fig. 5. Mean values of height of cuttings rooted under C-PE $\left(C_{R B}\right)$ or $P-P E\left(P_{R B}\right)$-covered rooting benches and then transplanted to C-PE $\left(\mathrm{C}_{\mathrm{T}}\right)$ or P-PE $\left(\mathrm{P}_{\mathrm{T}}\right)$-covered low tunnels. $\mathrm{C}_{\mathrm{RB}} \mathrm{C}_{\mathrm{T}}(\square), \mathrm{C}_{\mathrm{RB}} \mathrm{P}_{\mathrm{T}}(\diamond), \mathrm{P}_{\mathrm{RB}} \mathrm{C}_{\mathrm{T}}$ $(\square)$, and $\mathrm{P}_{\mathrm{RB}} \mathrm{P}_{\mathrm{T}}(\diamond)$. Vertical bars indicate $\pm \mathrm{SD}(\mathrm{n}=7)$. The vertical discontinuous line indicates the day of transplanting.

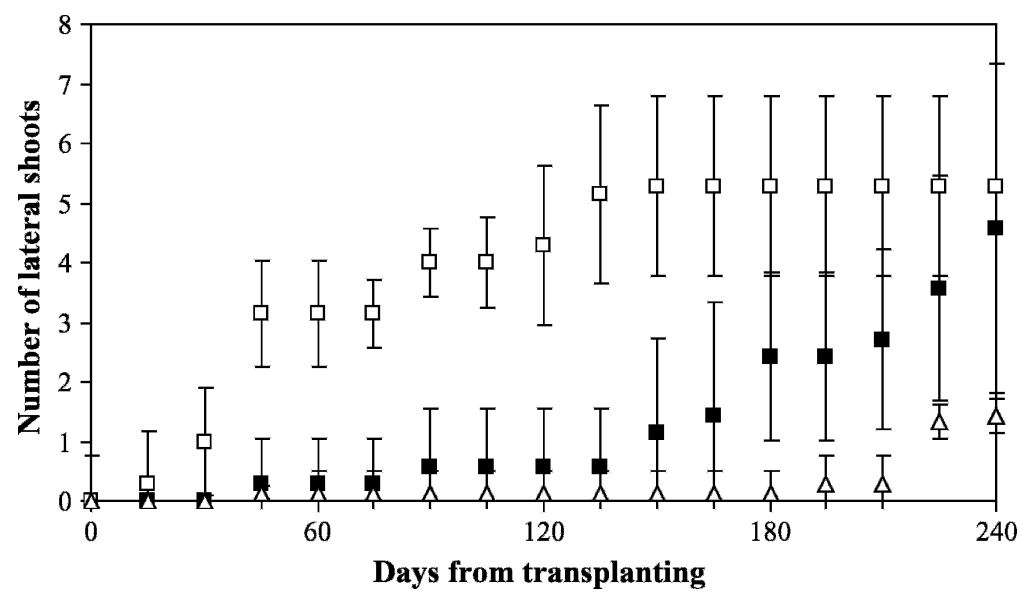

Fig. 6. Evolution in time of the number of lateral shoots of cuttings rooted under $C-P E\left(C_{R B}\right)$ or $P-P E\left(P_{R B}\right)$ -covered rooting benches and then transplanted to $\mathrm{C}-\mathrm{PE}\left(\mathrm{C}_{\mathrm{T}}\right)$ or P-PE $\left(\mathrm{P}_{\mathrm{T}}\right)$-covered low tunnels. $\mathrm{C}_{\mathrm{RB}} \mathrm{C}_{\mathrm{T}}(\square), \mathrm{C}_{\mathrm{RB}} \mathrm{P}_{\mathrm{T}}(\Delta), \mathrm{P}_{\mathrm{RB}} \mathrm{C}_{\mathrm{T}}(\mathbf{\square})$. Vertical bars indicate $\pm \mathrm{SD}(\mathrm{n}=7)$.

Table 4. Leaves and shoots fresh (fwt) and dry (dwt) weight $(\mathrm{g})$ and leaf area (LA, $\left.\mathrm{mm}^{2}\right)$ of cuttings rooted under C-PE $\left(\mathrm{C}_{\mathrm{RB}}\right)$ or P-PE $\left(\mathrm{P}_{\mathrm{RB}}\right)$-covered rooting bench and then transplanted to C-PE $\left(\mathrm{C}_{\mathrm{T}}\right)$ or P-PE $\left(\mathrm{P}_{\mathrm{T}}\right)$-covered low tunnels.

\begin{tabular}{lccccr}
\hline Treatment & Leaves fwt & Shoots fwt & Leaves dwt & Shoots dwt & LA \\
\hline $\mathrm{C}_{\mathrm{RB}} \mathrm{C}_{\mathrm{T}}$ & $3.97 \mathrm{a}$ & $1.83 \mathrm{a}$ & $1.25 \mathrm{a}$ & $0.62 \mathrm{a}$ & $11,351.3 \mathrm{a}$ \\
$\mathrm{C}_{\mathrm{RB}} \mathrm{P}_{\mathrm{T}}$ & $4.61 \mathrm{a}$ & $2.17 \mathrm{a}$ & $1.07 \mathrm{a}$ & $0.52 \mathrm{a}$ & $12,582.5 \mathrm{a}$ \\
$\mathrm{P}_{\mathrm{RB}} \mathrm{C}_{\mathrm{T}}$ & $5.66 \mathrm{a}$ & $1.56 \mathrm{a}$ & $1.39 \mathrm{a}$ & $0.43 \mathrm{a}$ & $12,549.2 \mathrm{a}$ \\
$\mathrm{P}_{\mathrm{RB}} \mathrm{P}_{\mathrm{T}}$ & $0.48 \mathrm{~b}$ & $0.24 \mathrm{~b}$ & $0.13 \mathrm{~b}$ & $0.1 \mathrm{~b}$ & $1,784.2 \mathrm{~b}$ \\
\hline
\end{tabular}

Using Student's $t$ test means within a column followed by the same letter are not significantly different at $P=0.05$.

observed for NIR radiation, whereas total radiation was reduced $\approx 43 \%$ under the P-PE film. Subsequent modifications were observed in the PAR:total and PAR:NIR ratios, the values of the ratios being $\approx 36 \%$ and $50 \%$ lower under the P-PE film, indicating the reduction of $P A R$ with respect to total and NIR radiation as mentioned previously.

Measurements presented in Figure 1 and estimations presented in Table 2 indicated that the P-PE film induces a strong $P P F D$ reduction and a light quality modification within the range of the two forms of phyto- respectively, compared with $\zeta_{\mathrm{n}}$ and $\mathrm{B}: \mathrm{R}$ values calculated under the C-PE film. The values of $\varphi$ presented in Table 3 are similar to those reported by Oyaert et al. (1999), who also observed plant height reduction under similar light quality conditions. These light quality modifications can lead to the production of shorter (Oyaert et al., 1999; Runkle and Heins, 2002) but also weaker plants (Wilson and Rajapakse, 2001). Accordingly, it has to be emphasized that the involvement of blue light on plant response must be considered. As is also stressed by Casal and Smith (1989), it seems that blue light inhibits internode extension only if it is combined with low $\zeta_{b}$ values.

Effects on cuttings. Cuttings rooted under the P-PE-covered rooting bench were $\approx 69 \%$ shorter than cuttings rooted under the C-PEcovered rooting bench (Fig. 2). Only a small change in plant height was observed after $60 \mathrm{~d}$ in culture for all treatments because flower differentiation of the apical bud was induced and the height of the main shoot was no further increased after Day 105. The previously mentioned results on plant height were attributed to the high $\zeta_{n}$ and high $\mathrm{B}: \mathrm{R}$ values observed under the P-PE film compared with those observed under the C-PE film (Khattak and Pearson, 2006; Rajapakse et al., 1993). The height reduction observed in the present study is higher compared with what is referred by other authors for other plant species (Oyaert et al., 1999; Rajapakse et al., 2000; Wilson and Rajapakse, 2001). It has been observed that height reduction is related to $\zeta_{n}$ values and B:R ratio and/or light intensity. Oyaert et al. (1999) found that for chrysanthemum plants, growth inhibition under colored polyethylene plastic films increased from $11 \%$ to $22 \%$ when $\mathrm{B}: \mathrm{R}$ increased from 6.20 to 85.53 , and $\zeta_{\mathrm{b}}$ and $\zeta_{\mathrm{n}}$ values decreased from 0.31 to 0.03 and 1.45 to 0.43 , respectively. It has to be noted that cuttings placed under the P-PE rooting bench received $\approx 60 \%$ less $P A R$ radiation than those grown under the $\mathrm{C}$-PE rooting bench (Table 2). However, according to Kamoutsis et al. (1999), 67\% lower PAR light level had no effect on gardenia plants height and accordingly, the lower $P A R$ radiation levels observed in the present study are considered to have no or very low effect on shoot length reduction.

Effects on potted plants. $\mathrm{C}_{\mathrm{RB}} \mathrm{P}_{\mathrm{T}}$ plants that were grown under high $\mathrm{R}_{\mathrm{n}}: \mathrm{FR}_{\mathrm{n}}$ and high $\mathrm{B}: \mathrm{R}$ ratios after transplanting were only $26 \%$ shorter than $\mathrm{C}_{\mathrm{RB}} \mathrm{C}_{\mathrm{T}}$ plants, whereas $\mathrm{P}_{\mathrm{RB}} \mathrm{C}_{\mathrm{T}}$ plants grown only during their rooting period under a modified light regime were $56 \%$ shorter than $\mathrm{C}_{\mathrm{RB}} \mathrm{C}_{\mathrm{T}}$, indicating that light modifications on plant height reduction were more effective at the early stage of plant development. $\mathrm{C}_{\mathrm{RB}} \mathrm{C}_{\mathrm{T}}$ and $\mathrm{P}_{\mathrm{RB}} \mathrm{C}_{\mathrm{T}}$ plants received almost the same $P P F D$ (mean daily total PPFD: $13.2 \mathrm{~mol} \cdot \mathrm{m}^{-2} \cdot \mathrm{d}^{-1}$ and 12.9 $\mathrm{mol} \cdot \mathrm{m}^{-2} \cdot \mathrm{d}^{-1}$, respectively) during the growth period and accordingly, the plant height differences observed between the two treatments can be attributed to $B: R$ and $R: F R$ differences of the cover materials. 
Comparing $\mathrm{P}_{\mathrm{RB}} \mathrm{P}_{\mathrm{T}}$ and $\mathrm{P}_{\mathrm{RB}} \mathrm{C}_{\mathrm{T}}$ plants, we could conclude that growth of cuttings under high $\mathrm{B}: \mathrm{R}$ and high $\zeta_{\mathrm{n}}$ ratios for a period of $15 \mathrm{~d}$ is adequate to induce the appropriate plant height reduction and that further growth of plants under the same light regime does not further modify their height significantly.

The established inhibitory effect of blue light on cell expansion (Cosgrove, 1981) could explain the reduction of LA of cuttings grown under the P-PE film. A higher reduction in LA $(\approx 50 \%)$ was reported for chrysanthemum grown under blue PE films with lower B:R values than that of P-PE film and similar $\zeta_{n}$ values (Oyaert et al., 1999).

Existing leaves or new leaves expanded soon after placing the cuttings under the P-PE film were unaffected by light quality modifications induced by the film. In contrast, leaves differentiated and developed under the P-PE film were smaller. Similar effects were reported for white clover plants developed under blue light (Gautier et al., 1997).

A major characteristic of compact gardenia plants is the great number of lateral shoots that shape a spherical plant with many flower buds. Accordingly, a high number of lateral shoots is desirable. At the end of the experimental period of potted plants, $\mathrm{C}_{\mathrm{RB}} \mathrm{C}_{\mathrm{T}}$ plants had an average of $5.2( \pm 1.5)$ developed lateral shoots, whereas $\mathrm{C}_{\mathrm{RB}} \mathrm{P}_{\mathrm{T}}$ plants had very few and $\mathrm{P}_{\mathrm{RB}} \mathrm{P}_{\mathrm{T}}$ had no lateral shoots developed and thus were characterized of a very low quality because they did not have the appropriate shape and volume and bear only a few flower buds. Similar results were found for chrysanthemum grown under low $P P F D$ and high B:R (Assmann, 1992; Oyaert et al., 1999). However, $P_{R B} C_{T}$ plants had a very good compact and spherical shape because they were short and had the same number of lateral shoots as the $\mathrm{C}_{\mathrm{RB}} \mathrm{C}_{\mathrm{T}}$ plants. Accordingly, it seems that the best treatment for obtaining well-shaped compact gardenia plants is to keep the plants during rooting period under high $\mathrm{B}: \mathrm{R}$ and high $\zeta_{\mathrm{n}}$ values and locate them under a natural light environment for the rest of the growing period. It was found that this technique did not affect plant LA or leaf and shoot fresh and dry weight in contrast to the results found by Leakey and Storeton-West (1992) who observed that low irradiance and high $\zeta_{b}$ values affected rooting and, in consequence, growth rate and shoot length of cuttings through direct effects on photosynthesis and on assimilate production. The fact that gardenia is a shadow plant (Kamoutsis et al., 1999) may be a reason for this different response.

\section{Conclusion}

Photoselective plastic films with high $\zeta_{n}$ values and high $B: R$ ratios are able to reduce the height of gardenia plants. However, continued development of gardenia plants under a P-PE film results into unmarketable, low-quality plants without lateral shoots and, as a consequence, a low number of flowers. In addition, more attention must be paid to the use of photoselective cover materials with high reduction of $P A R$ radiation when they are going to be used for gardenia production in areas or during periods with very low radiation, because a reduction of $60 \%$ of $P A R$ could be a real constrain for the proper growth of the plants. Light with high $\zeta_{n}$ values and high $B: R$ ratios was more effective for height reduction of gardenia potted plants when applied in early stages during the rooting period of cuttings. Rooting of cuttings under the P-PE film followed by growth of rooted plants under C-PE film could be a practice resulting in a drastic reduction of plant height without affecting the leaf area, shoot and leaf fresh and dry weight as well as the number of lateral shoots, which is important for a well-shaped compact plant. This, in combination with the fact that no further increase of shoot height takes place after flower differentiation of the apical bud, reduces the need for placement of plants during late growth stages under the lightfiltering plastic films. In addition, placing cuttings rather than potted plants under the light-filtering plastic film is a more manageable practice. The use of photoselective plastic films for the production of potted compact gardenia plants can contribute to the reduction of chemical use because, according to the growers' practice (Gardenia Growers Group, personal communication), 200 to $300 \mathrm{~L} \cdot \mathrm{ha}^{-1}$ per year of chemical growth retardants is used for gardenia plant height control. This results in more than 6000 $€$ production cost reduction per hectare and year.

\section{Literature Cited}

Assmann, S.M. 1992. Effects of light quantity and quality during development on the morphology and stomatal physiology of Commelina communis. Oecologia 92:188-195.

Britz, S.J. and J.C. Sager. 1990. Photomorphogenesis and photoassimilation in soybean and sorghum grown under broad spectrum or blue-deficient light sources. Plant Physiol. $94: 448-454$

Casal, J.J. and H. Smith. 1989. Effects of blue light pretreatments om internode extension growth in mustard seedlings after transition to darkness: Analysis of the interaction with phytochrome. J. Expt. Bot. 40:893-899.

Cerny, T.A., J. Faust, D. Layne, and N.C. Rajapakse. 2003. Influence of photoselective films and growing season on stem growth and flowering of six plant species. J. Amer. Soc. Hort. Sci. 128:486-491.

Chen, M., J. Chory, and C. Fankhauser. 2004 Light signal transduction in higher plants. Annu. Rev. Genet. 38:87-117.

Conover, C.A., T.J. Sheeman, and R.T. Poole. 1968. Flowering of gardenias as affected by photoperiod, Cycocel and B-9. Fla. Agric. Exp. Stn. Journal Series. 3116. University of Florida, Gainesville, FL. p. 401-408.

Cosgrove, D.J. 1981. Rapid suppression on growth by blue light. Plant Physiol. 67:584-590.

De Baerdemaeker, C.I., J.M. Van Huylenbroeck, and P.C. Debergh. 1994. Influence of paclobutrazol and photoperiod on growth and flowering of Gardenia jasminoides Ellis cultivar 'Veitchii'. Sci. Hort. 58:315-324.

De Graaf-Van, R. and M.T.H. Der Zande. 1988. Teeltonderzoek Gardenia jasminoides. Proef- station voor de Bloemisterij. Rapport 56 . Aalsmeer, Nededand.

Everett, M.S. and W.R. Briggs. 1970. Some spectral properties of pea phytochrome in vivo and in vitro. Plant Physiol. 45:679-683.

Gautier, H., C. Varlet-Grancher, and N. Baudry. 1997. Effects of blue light on the vertical colonization of space by white clover and their consequences of dry matter distribution. Ann. Bot. (Lond.) 80:665-671.

Holmes, M.G. and H. Smith. 1977. The function of phytochrome in the natural environment. I. Characterization of daylight for studies in photomorphogenesis and photoperiodism. Photochem. Photobiol. 25:533-538.

Kamoutsis, A.P., A.G. Chronopoulou Sereli, and E.A. Paspatis. 1999. Paclobutrazol affects growth and flower bud production in gardenia under different light regimes. HortScience 34:674-675.

Khattak, A.M. and S. Pearson. 2006. Spectral filters and temperature effects on the growth and development of chrysanthemums under low light integral. Plant Growth Regulat. 49:61-68.

Khattak, A.M., S. Pearson, and C.B. Johnson. 2004. The effects of far red spectral filters and plant density on the growth and development of chrysanthemums. Sci. Hort. 102:335-341.

Kittas, C. and A. Baille. 1998. Determination of the spectral properties of several greenhouse cover materials and evaluation of specific parameters related to plant response. J. Agr. Eng. Res. 71: 193-202.

Kittas, C., A. Baille, and P. Giaglaras. 1999. Influence of covering material and shading on the spectral distribution of light in greenhouses. J. Agr. Eng. Res. 73:341-351.

Larson, R.A. 1992. Introduction to floriculture. 2nd Ed. Academic Press, San Diego, CA.

Leakey, R.R.B. and R. Storeton-West. 1992. The rooting ability of Triplochiton scleroxylon cuttings: The interaction between stockplant irradiance, light quality and nutrients. For. Ecol. Manage. 49:133-150.

Maas, F.M. and E.J. Bakx. 1995. Effects of light on growth and flowering of Rosa hybrida 'Mercedes'. J. Amer. Soc. Hort. Sci. 120:571-576.

Mortensen, L.M. and E. Strømme. 1987. Effect of light quality on some greenhouse crops. Sci. Hort. 33:27-36.

Muir, R.M. and L. Zhu. 1983. Effect of light in the control of growth by auxin and its inhibitor(s) in the sunflower. Physiol. Plant. 57:407-410.

Murakami, K., H. Cui, M. Kiyota, T. Yamane, and I. Aiga. 1997. Control of plant growth by covering materials for greenhouses which alter the spectral distribution of transmitted light. Acta Hort. 435:123-130.

Oyaert, E., E. Volckaert, and P.C. Debergh. 1999. Growth of chrysanthemum under coloured plastic films with different light qualities and quantities. Sci. Hort. 79:195-205.

Pobudkiewicz, A. and J. Treder. 2006. Effects of flurprimidol and daminozide on growth and flowering of oriental lily 'Mona Lisa'. Sci. Hort. 110:328-333.

Pratt, L.H. and W.R. Briggs. 1966. Photochemical and nonphotochemical reactions of phytochrome in vivo. Plant Physiol. 41:467-474.

Rajapakse, N.C., T. Cerny, and S.B. Wilson. 2000. Photoselective covers for plant growth regulation. FlowerTech. 3:32-35.

Rajapakse, N.C. and J.W. Kelly. 1995. Spectral filters and growing season influence growth and carbohydrate status of chrysanthemum. J. Amer. Soc. Hort. Sci. 120:78-83.

Rajapakse, N.C., M.J. McMahon, and J.W. Kelly. 1993. End of day far-red light reverses height 
reduction of chrysanthemum induced by $\mathrm{CuSO}_{4}$ spectral filters. Sci. Hort. 53:249259.

Rajapakse, N.C., R.E. Young, M.J. McMahon, and R. Oi. 1999. Plant height control by photoselective filters: Current status and future prospects. HortTechnology 9:618-624.

Runkle, E.S. and R.D. Heins. 2002. Stem extension and subsequent flowering of seedlings grown under a film creating a far-red deficient environment. Sci. Hort. 96:257-265.
Sager, J.C., W.O. Smith, J.L. Edwards, and K.L. Cyr. 1988. Photosynthetic efficiency and phytochrome photoequilibria determination using spectral data. Trans. ASAE 31:18821889.

Smith, H. 1982. Light quality, photoperception, and plant strategy. Annu. Rev. Plant Physiol. $33: 481-518$

Spalding, E.P. and K.M. Folta. 2005. Illuminating topics in plant photobiology. Plant Cell Environ. 28:39-53.
Van Haeringen, C.J., J.S. West, F.J. Davis, A Gilbert, P. Hadley, R.G.C. Henbest, S. Pearson, and A.E. Wheldon. 1998. The development of solid spectral filters for the regulation of plant growth. Photochem. Photobiol. 64:407-413.

Warpeha, K.M. and L.S. Kaufman. 1989. Bluelight regulation of epicotyl elongation in Pisum sativum. Plant Physiol. 89:544-548.

Wilson, S.B. and N.C. Rajapakse. 2001. Use of photoselective plastic films to control growth of three perennial salvias. J. Appl. Hort. 3:71-74. 